\title{
Public health concern behind the exposure to persistent organic pollutants and the risk of metabolic diseases
}

Jérôme Ruzzin ${ }^{*}$

\begin{abstract}
Background: Persistent organic pollutants (POPs) are hazardous chemicals omnipresent in our food chain, which have been internationally regulated to ensure public health. Initially described for their potency to affect reproduction and promote cancer, recent studies have highlighted an unexpected implication of POPs in the development of metabolic diseases like type 2 diabetes and obesity. Based on this novel knowledge, this article aims at stimulating discussion and evaluating the effectiveness of current POP legislation to protect humans against the risk of metabolic diseases. Furthermore, the regulation of POPs in animal food products in the European Union (EU) is addressed, with a special focus on marine food since it may represent a major source of POP exposure to humans.
\end{abstract}

Discussion: There is mounting scientific evidence showing that current POP risk assessment and regulation cannot effectively protect humans against metabolic disorders. Better regulatory control of POPs in dietary products should be of high public health priority.

Summary: The general population is exposed to sufficient POPs, both in term of concentration and diversity, to induce metabolic disorders. This situation should attract the greatest attention from the public health and governmental authorities.

\section{Background}

The incidence of obesity and diabetes has dramatically increased worldwide. From 1980 to 2008, the global prevalence of obesity has doubled in both men and women [1], whereas the number of people with diabetes increased from 153 million in 1980 to 347 million in 2008 [2]. A recent report realised in the European Union (EU) highlights that overweight and obesity affect more than $50 \%$ of the adult population whereas diabetes is now affecting over 30 million people [3]. In the United States (US), the prevalence of obesity among children and adolescents has almost tripled since 1980 [4], and $12 \%$ of children aged 2 through 5 years were obese in 2009-2010 [5]. In addition to enhancing the risk of premature death, diabetes and obesity are major causes of multiple complications, including hypertension, cardiovascular diseases, asthma, blindness, limb amputation,

Correspondence: jerome.ruzzin@bio.uib.no

Department of Biology, University of Bergen, Postboks 7803, 5020 Bergen, Norway

C Biomed Central and sleep apnea, that generate enormous economic costs for both health care and loss of productivity to society. Total annual economic cost of diabetes in the US reached $\$ 132$ billion in 2002, representing around 11\% of the US health care expenditure, and increased to $\$ 174$ billion in 2007 [6,7]. In Europe, obesity-related healthcare was estimated to reach up to 10.4 billion Euros [8].

Although they are the focus of intense investigations, the origins of metabolic diseases have remained poorly understood. While there is certainly genetic predisposition, the rapid and explosive incidence of obesity and type 2 diabetes cannot be due to genetic modifications in the population. Indeed, the propagation of these diseases is simply too fast to lie at the feet of genetic changes. Rather, environmental factors like physical inactivity and consumption of high-energy diets are likely to be important contributors. However, the view that these two conventional risk factors alone are the primary variables explaining the epidemic of metabolic diseases is being challenged as far too simplistic [9-12]. 
Persistent organic pollutants (POPs), including dioxins, furans, polychlorinated biphenyls (PCBs), and organochlorine pesticides, are chemicals mainly created by industrial activities, either intentionally or as by-products [13]. Because of their ability to resist environmental degradation, these substances are omnipresent in food products, and found all around the world, even in areas where they have never been used like Antarctica [14]. Thus, virtually all humans are daily exposed to POPs. In the general population, exposure to POPs comes primarily from the consumption of animal fat like fatty fish, meat and milk products; the highest POP concentrations being commonly found in fatty fish [15-26].

POPs are lipophilic chemicals that can pass through biological phospholipid membranes and bio-accumulate in fatty rich tissues of humans. Initially described for their deleterious effects on reproductive function and carcinogenicity, there is now growing body of evidence showing that exposure to POPs leads to metabolic diseases. First, many epidemiological studies performed in the US, Europe and Asia have led to the common finding that there is an increased body burden of POPs in people with diabetes [27-39]. For instance, diabetes has been associated with elevated serum levels of 2,3,7,8-tetrachlorodibenzodioxin (TCDD), 2,2',4,4',5,5'-hexachlorobiphenyl (CB153), coplanar polychlorinated biphenyls (PCBs; CB77, CB81, CB126, CB169), p,p'-diphenyldichloroethene (DDE), oxychlordane and trans-nonachlor. In addition, bio-accumulation of PCBs has been linked to non-alcoholic fatty liver disease (NAFLD) and elevated blood pressure [40,41]. Recently, prospective studies have furthermore shown an increased risk of diabetes in persons exposed to POPs, especially organochlorine pesticides $[39,42,43]$. Second, there is evidence for a causal relationship between POP exposure and metabolic disorders linked to insulin resistance. Animals exposed to environmental levels of POP mixtures through the intake of non-decontaminated fish oil (obtained from farmed Atlantic salmon) exhibited insulin resistance, glucose intolerance, abdominal obesity and NAFLD [44]. In rats fed decontaminated crude salmon oil, which contained very low levels of POPs, these metabolic disturbances were almost absent. Importantly, the body burden of POPs in rats exposed to non-decontaminated salmon oil did not exceed those observed in humans 40-50 years of age, thereby underlying that the animals were not over-exposed to POPs [44]. Further, the presence of POPs in farmed Atlantic salmon fillet was found to accelerate the development of visceral obesity and insulin resistance in mice [45]. Other studies exposing rodent to single POP compound reported metabolic dysfunctions like NAFLD or increased body weight gain $[46,47]$. Third, in vitro investigations showed that POPs are powerful disruptors of metabolic homeostasis [44-46,48], which is consistent with the obesogen properties of some xenobiotics [49]. Taken together, these findings observed in humans, animals, and cell models, demonstrate that POPs are potent environmental contributors to metabolic diseases. Based on this novel knowledge, the present article aims to stimulate discussion and to evaluate the effectiveness of current POP legislation to protect humans against the risk of metabolic diseases.

\section{Discussion}

\section{Current regulation and risk assessment of POPs}

To protect humans, the United Nations Environment Programme (UNEP), in 1997, issued an international action to reduce the global release of 12 POPs, the "dirty dozen", which included nine organochlorinated pesticides; aldrin, chlordane, dichlorodiphenyltrichloroethane (DDT), dieldrin, endrin, heptachlor, hexachlorobenzene, mirex, toxaphene, and three industrial chemicals; dioxins, furans, and PCBs. In 2001, the Stockholm Convention on POPs was ratified by 151 signatories, and the Convention entered into force three years later [50].

Aldrin, chlordane, DDT, dieldrin, endrin, heptachlor, mirex, and toxaphene were extensively used in agriculture as insecticides, whereas hexachlorobenzene was used as a fungicide. By 1990, these POPs were prohibited for use on crops and termite control by most European and North American countries because of their potential threat to human health [51]. DDT has also been utilized in indoor spraying for control of vectors of malaria, dengue, visceral leishmaniasis, and Chagas disease, and its use for the purpose of controlling disease vectors has been permitted by the Stockholm Convention, in accordance with recommendations and guidelines of the World Health Organization (WHO) [52]. In its Position Statement, WHO stipulates that a sudden ban on DDT use could have significant consequences for the burden of malaria because of the absence of equally effective and efficient alternatives [52]. The use of DDT in malaria prevention has led to intense debates because it can save many lives but DDT may, at the same time, induce adverse human health effects [53-55]. In 2005, the global production of DDT used for disease vector control was estimated to reach 5,000 metric tons [56]. Up to 160 metric tons of DDT were still produced for agriculture purposes [56], and the production of other organochlorine pesticides, like aldrin and dieldrin, is suspected to occur in different countries [51]. Not surprisingly, a recent US monitoring study revealed that DDT and its metabolites as well as endosulfan and aldrin, are still largely present in food, and daily consumed by humans [19].

The term "dioxins" is commonly used to refer a group of 75 polychlorinated dibenzo-p-dioxins (PCDDs) and 135 polychlorinated dibenzofurans (PCDFs) congeners among which less than 20 are believed to be toxic. Dioxin likePCBs (dl-PCBs) refer to 12 non-ortho or mono-ortho PCBs 
exhibiting similar biological pattern to dioxins. In 1997, an expert committee, set up by the WHO, developed the concept of toxic equivalent factors (TEF) to facilitate risk assessment and regulatory control of exposure to mixtures of PCDDs, PCDFs, and dl-PCBs [57]. TEF is based on in vitro and in vivo data showing that PCDD, PCDF and dl-PCB congeners induce similar toxic responses to those caused by TCDD, which is considered as the most potent toxic congener $[57,58]$. Thus, TEF is an order of magnitude estimate of the toxicity of a compound relative to TCDD. The criterion to apply a TEF to a POP congener is the following:

1) The chemical must show a structural relationship to PCDDs and PCDFs.

2) The chemical must bind the aryl hydrocarbon receptor (AhR) and elicit AhR-mediated biochemical and toxic responses.

3) The chemical must be ubiquitous in the food chain.

To further estimate the toxicity of POP mixtures to which humans and organisms can be exposed, TEF values are used to calculate toxic equivalent (TEQ) concentrations as follows: TEQ $=\Sigma_{\mathrm{n} 1}\left(\mathrm{PCDDs}_{\mathrm{i}} \times \mathrm{TEF}_{\mathrm{i}}\right)+\Sigma_{\mathrm{n} 2}\left(\mathrm{PCDFs}_{\mathrm{i}} \times\right.$ $\left.\mathrm{TEF}_{\mathrm{i}}\right)+\Sigma_{\mathrm{n} 3}\left(\mathrm{dl}-\mathrm{PCBs}_{\mathrm{i}} \times \mathrm{TEF}_{\mathrm{i}}\right)$. This approach assumes that the combined effects of different PCDD, PCDF and dl-PCB congeners produce additive toxic effects.

The Stockholm Convention has led to substantial reduction of POP production. Dietary surveys have reported that the concentrations of organochlorine pesticides, dioxins, and PCBs have declined in most food products [20,59,60]. Furthermore, many studies characterizing the temporal trends of these classical POPs in human blood showed that the concentrations of these pollutants have decreased during the last years [61-64], although the human body burden of so-called "emerging" POPs, like polybrominated diphenyl ether (PBDE) and some perfluorinated compounds, have remained stable or even increased [65-67]. The present situation may therefore indicate that the current background exposure to POPs is still sufficient to perturb hormonal and metabolic homeostasis of the human body.

In general, safety guidelines have been performed by identifying the most sensitive effects of single POP, and has mainly focused on TCDD and its impacts on immunotoxicity, carcinogenotoxicity, reproductive and developmental toxicity in animals. In 2000, the Scientific Committee on Food (SCF) of the European Commission reviewed extensive data and experimental results and recommended a tolerable weekly intake (TWI) of $7 \mathrm{pg}$ WHO-TEQ/ $\mathrm{kg}$ body weight to protect consumers from the harmful effects associated with environmental contaminant exposure through consumption of food products [68]. Only six months later, the SCF reassessed the TWI by focusing on non-carcinogenetic endpoints only [69], and increased the TWI from 7 to $14 \mathrm{pg}$
WHO-TEQ/kg body weight based on rat studies investigating the reproductive effects of male offspring [70]. Below this level, contaminants are expected to have no effects or its effects are reversed by body's defence mechanisms. Today, various authorities have defined their own maximum daily exposure limits, tolerable daily intake (TDI), within the range of 1 to $4 \mathrm{pg} \mathrm{WHO}-\mathrm{TEQ} / \mathrm{kg}$ body weight/day. Still, although some population has TDI below national ranges, many studies have documented that exposure to dioxins and dl-PCBs to humans, especially children, can be above the recommended TDI levels [15,21,23,24,59,71,72].

\section{Main limitations of current risk assessment on POPs in relation with metabolic disorders}

1) TEQ and the concept of additive toxic effects. Although TEQ concept is based on additive effects of pollutants, i.e. high doses of a chemical are expected to cause greater deleterious effects than low doses, not all studies on environmental pollutants and xenobiotics support this concept [42,73-77]. Accumulating data continue to underline the existence of a non-linear or inverted relationship between environmental pollutants and their detrimental effects; strong biological effects in low dose of exposure but weak or no effects in higher dose. For instance, exposure to low concentrations of TCDD and 1,2,3,4,7,8-hexachlorodibenzo- $p$ dioxin (HxCDD) increased body weight gain in rats whereas at higher doses of exposure, both TCDD and $\mathrm{HxCDD}$ decreased body weight [46]. Consistently, low doses of CB-77 and TCDD were found to promote adipocyte differentiation whereas higher doses resulted in the absence of cell differentiation [48]. Furthermore, 3T3-L1 adipocytes incubated with low concentration of CB-77 stimulated adipokine release whereas this effect was absent when cells were exposed to high CB-77 concentration. Overall, the assumption that the combined effects of different congeners are doseadditive, which is the most important prerequisite of the TEQ concept, is highly questionable and linear extrapolation procedure is likely to under-estimate the metabolic risks linked to POP exposure.

2) TEF, TEQ and the assumption that dioxins and dlPCBs exhibit similar types of biological effects through interaction with AhR. TEF concept assumes that, among POPs, TCDD is the most toxic chemical. Therefore, the potency of dioxins, furans and dl-PCBs has been expressed as fractions of the potency of TCDD. Although TCDD, through AhR activation, may induce cancer, reproduction and neuronal dysfunctions, TEQ is unlikely to predict the risk of metabolic disorders induced by POP 
exposure. For instance, the ability of different POP mixtures to impair insulin action in 3T3L1 adipocytes was reported to be independent of TEQ (Figure 1). Both PCDD and PCDF mixtures did not impair insulin-stimulated glucose uptake compared with vehicle-treated cells, whereas non- and monoortho-PCB mixtures induced significant disruption of insulin action (Figure 1). Interestingly, the stimulation of glucose uptake induced by insulin was highly impaired after exposure to mixtures of organochlorine pesticides. These in vitro findings are consistent with many human studies indicating that POPs increase the risk of diabetes independently of $\mathrm{TEQ}$, and that some organochlorine pesticides, like trans-nonachlor, are more strongly associated with diabetes than other POPs $[29,42,78]$. Consistently, in vitro experiments using single POP compound reported that, at similar TEQ value, CB-77 stimulated adipocyte differentiation whereas this effect was absent in cells treated with TCDD [48]. In concert, these results suggest that the deleterious metabolic effects associated with POP exposure may occur independently of AhR activation. Potential modes of action of POPs may include activation of constitutive androstane receptor (CAR) or steroid xenobiotic receptor (SXR), and competitive binding to nuclear receptors $[79,80]$.

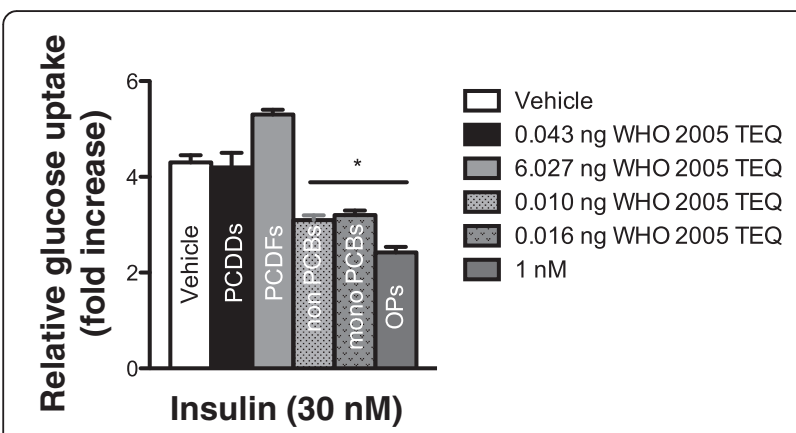

Figure 1 Effect of POP mixtures on insulin action. Differentiated 3T3-L1 adipoctytes were incubated for $48 \mathrm{~h}$ with different POP mixtures mimicking those present in the oil of farmed Atlantic salmon. The ability of insulin (30nM) to stimulate glucose uptake was assessed. Note that the PCDF mixture and its elevated TEQ value did not impair insulin-stimulated glucose uptake. At the opposite, PCB mixtures and their low TEQ values significantly impaired insulin action. The most important inhibitory effect on insulin action was observed after exposure to organochlorine pesticides (1nM). PCDDs, polychlorinated dibenzo-p-dioxins; PCDFs, polychlorinated dibenzofurans; PCBs, polychlorinated biphenyls; OPs, organochlorine pesticides. Data are expressed as relative glucose uptake and presented as mean \pm SEM. ${ }^{*} p<0.05$; Data are adapted from [44].
3) Adult and early life exposure. There is a special concern regarding children because regulatory policies, which established dioxins and dl-PCBs tolerable intake on a body weight basis, do not distinguish between children and adults. Because of their high food intake per kilogram body weight required to maintain whole-body homeostasis and growth, children are likely to be at higher risk for environmental pollutant exposure. Not surprisingly, many scientific studies have highlighted that children are over-exposed to dioxins and dl-PCBs, and exceed the TDI of $2 \mathrm{pg} / \mathrm{kg}$ body weight [15,21,23,81-87]. Furthermore, both metabolism, absorption and excretion system are different in children compared with adults, so that this subpopulation may potentially be more responsive to environmental pollutants [88]. Another important issue concerns foetal life. Generally, pregnant women have been advised to avoid the consumption of food containing elevated levels of POPs, as well as other environmental pollutants like heavy metals. However, POPs bio-accumulate in the body for many years, and restricting the exposure to these pollutants only during pregnancy would not protect the foetus or the future generations against the harmful effects of these hazardous chemicals [89].

\section{Inconsistency of POP regulation in animal food products: the case of marine food}

The omnipresence of POPs in animal food products has led international and national authorities to set up maximum limits. In this regard, marine food has attracted great interest and has been the source of intense debates [90-92]. In the EU, maximum limit of dioxins, furans and dl-PCBs in fish and seafood products have been set to $8 \mathrm{pg}$ WHO $1998 \mathrm{TEQ} / \mathrm{g}$ fresh weight [93]. Giving that these POPs are highly lipophilic and therefore mainly present in the fat fraction of fish, this concentration could reach around $70 \mathrm{pg}$ WHO $1998 \mathrm{TEQ} / \mathrm{g}$ fat for a fatty fish (Table 1). On the other hand, the maximum limit of dioxins, furans and dl-PCBs in marine oil has been set to $10 \mathrm{pg}$ WHO $1998 \mathrm{TEQ} / \mathrm{g}$ fat, a level that is seven times lower the one possibly observed in muscle meat of fatty fish. Thus, eating $1 \mathrm{~g}$ of fat from a fatty fish fillet could induce an exposure to $70 \mathrm{pg}$ WHO 1998 TEQ (depending on the fat content of fish), whereas consuming $1 \mathrm{~g}$ of fat from a marine oil product could lead to an exposure to $10 \mathrm{pg}$ WHO 1998 TEQ. Since the maximum levels for dioxins and dl-PCBs in foodstuffs should be set according to their potential harmful effects and risk to public health, one would expect these levels to be harmoniously regulated within food products. 
Table 1 Regulation of dioxins, furans and dl-PCBs in fish and other animal food products by the EU

Maximum levels of dioxins, furans and

dl-PCBs (WHO 1998 TEQ)

\section{Meat and meat

products from:

$\begin{array}{ll}\text { Ruminants: } & 4.5 \mathrm{pg} / \mathrm{g} \text { fat } \\ \text { Poultry and } & 4.0 \mathrm{pg} / \mathrm{g} \text { fat } \\ \text { farmed game: } & 1.5 \mathrm{pg} / \mathrm{g} \text { fat } \\ \text { Pigs: } & \end{array}$

\section{Muscle meat of \\ fish and \\ fishery products ${ }^{1}$ :}

$8.0 \mathrm{pg} / \mathrm{g}$ fresh weight $\quad(70.0 \mathrm{pg} / \mathrm{g} \mathrm{fat})^{2}$

\section{Fat products from:}

$\begin{array}{ll}\text { Ruminants: } & 4.5 \mathrm{pg} / \mathrm{g} \text { fat } \\ \text { Poultry and farmed game: } & 4.0 \mathrm{pg} / \mathrm{g} \text { fat } \\ \text { Pigs: } & 1.5 \mathrm{pg} / \mathrm{g} \text { fat } \\ \text { Marine oils: } & 10.0 \mathrm{pg} / \mathrm{g} \text { fat }\end{array}$

${ }^{1}$ except eel. ${ }^{2}$ assuming a fish fillet containing $12 \%$ fat like farmed Atlantic salmon.

Note that the maximum limits of POPs in ruminants, poultry and farmed game, and pigs are similar in the "Meat and meat products from" compared with "Fat products from". In contrast, "Muscle meat of fish and fishery products" could contain up to $70 \mathrm{pg}$ WHO $1998 \mathrm{TEQ} / \mathrm{g}$ fat, which is around seven times higher the maximum limit set in "Fat products from marine oils" (10 pg WHO $1998 \mathrm{TEQ} / \mathrm{g}$ fat). Adapted from [93].

Another important issue is the regulation of organochlorine pesticides, which are chemicals strongly linked to type 2 diabetes $[29,32,33,37,44,45]$ as well as breast and prostate cancer [94] and Parkinson disease [95]. As for dioxins, furans and dl-PCBs, the EU has set up maximum residue levels in or on food and feed of plant and animal origin [96]. Thus, fruits, vegetables, products of terrestrial animal origin, cereals, and other food items are regulated for their content in pesticides. However, levels of pesticides are still unregulated in fish and seafood in the EU. Similarly, there are still no maximum limits for PCBs in marine food. Because seafood represents one of the main sources of human exposure to POPs, and that POPs contribute to metabolic diseases, policy makers and stakeholders should urgently regulate and diminish the concentrations of POPs in seafood to protect the general population. Indeed, recent studies have reported an association between fish and seafood intake and type 2 diabetes in humans [97-99], and possible connection between farmed Atlantic salmon and the epidemic of type 2 diabetes has been suggested [100].

Further, some EU countries, like Finland and Sweden, have obtained dispensations to sell fish species from the Baltic sea, a highly polluted area where fish species can accumulate significant levels of POPs -dioxin levels higher than $4 \mathrm{pg} / \mathrm{g}$ fresh weight of muscle meat and fishery products are allowed [93]. Also, the maximum levels of dioxins and dl-PCBs in muscle meat of eel, a potential highly contaminated fish, reached 12 pg WHO $1998 \mathrm{TEQ} / \mathrm{g}$ fresh weight, in contrast to the $8 \mathrm{pg}$ WHO $1998 \mathrm{TEQ} / \mathrm{g}$ fresh weight of other fish species [93]. Such derogations likely rose from the fact that background contamination of certain foodstuffs is already very high -mainly because of human pollution- and that keeping maximum dioxins and dl-PCBs levels similar in all food products would result to declare considerable part of our present food supply unfit for human consumption [68]. Unfortunately, this strategy is not aimed to reduce human exposure to POPs and raise serious questions about the effectiveness of EU regulations to protect consumers.

\section{Summary}

The global prevalence of metabolic diseases like obesity and type 2 diabetes, and its colossal economic and social costs represent a major public health issue for our societies. There is now solid evidence demonstrating the contribution of POPs, at environmental levels, to metabolic disorders. Thus, human exposure to POPs might have, for decades, been sufficient and enough to participate to the epidemics of obesity and type 2 diabetes. Based on recent studies, the fundaments of current risk assessment of POPs, like "concept of additive effects" or "dioxins and dl-PCBs induced similar biological effects through AhR", appear unlikely to predict the risk of metabolic diseases. Furthermore, POP regulation in food products should be harmonized and re-evaluated to better protect consumers. Neglecting the novel and emerging knowledge about the link between POPs and metabolic diseases will have significant health impacts for the general population and the next generations.

\section{Competing interests}

I have no competing interests to declare.

\section{Acknowledgements}

I am grateful to my international and national collaborators, as well as the Research Council of Norway for financial support (\#204473).

\section{Author's information}

JR has been working on environmental factors linking to obesity and type 2 diabetes. During the last 5 years, his research studies have focused on environmental pollutants, and he demonstrated, for the first time, the causal role of POPs in the development of metabolic disorders. Recently, part his work was presented at the High Level Consultative Conference of the Environment and Public Health Community in Europe, Berlin-Potsdam, Germany.

Received: 15 November 2011 Accepted: 20 April 2012

Published: 20 April 2012

\section{References}

1. Finucane MM, Stevens GA, Cowan MJ, Danaei G, Lin JK, Paciorek CJ, Singh GM, Gutierrez HR, Lu Y, Bahalim AN, et al: National, regional, and global trends in body-mass index since 1980: systematic analysis of health examination surveys and epidemiological studies with 960 country-years and 9.1 million participants. Lancet 2011, 377:557-567. 
2. Danaei G, Finucane MM, Lu Y, Singh GM, Cowan MJ, Paciorek CJ, Lin JK, Farzadfar $F$, Khang $Y H$, Stevens GA, et al: National, regional, and global trends in fasting plasma glucose and diabetes prevalence since 1980: systematic analysis of health examination surveys and epidemiological studies with 370 country-years and 2.7 million participants. Lancet 2011, 378:31-40.

3. Economic Cooperation and Development: Health at a glance. Europe: OECD Publishing; 2010

4. Ogden CL, Carroll MD, Curtin LR, McDowell MA, Tabak CJ, Flegal KM: Prevalence of overweight and obesity in the United States, 1999-2004. JAMA 2006, 295:1549-1555.

5. Ogden CL, Carroll MD, Kit BK, Flegal KM: Prevalence of obesity and trends in body mass index among US children and adolescents, 1999-2010. JAMA 2012, 307:483-490

6. American Diabetes Association: Diabetes Statistics. http://www.diabetes.org/ diabetes-basics/diabetes-statistics.

7. Center for Disease Control and Prevention: National Diabetes Fact Sheet, Data and Trends.2011.

8. Muller-Riemenschneider F, Reinhold T, Berghofer A, Willich SN: Healtheconomic burden of obesity in Europe. Eur J Epidemiol 2008, 23:499-509.

9. Ruzzin J, Lee DH, Carpenter DO, Jacobs DR Jr: Reconsidering metabolic diseases: the impacts of persistent organic pollutants. Atherosclerosis. in press.

10. Baillie-Hamilton PF: Chemical toxins: a hypothesis to explain the global obesity epidemic. J Alt Comp Med 2002, 8:185-192.

11. Thayer KA, Heindel JJ, Bucher JR, Gallo MA: Role of Environmental Chemicals in Diabetes and Obesity: A National Toxicology Program Workshop Report. Environ Health Perspect. in press.

12. Holtcamp W: Obesogens: an environmental link to obesity. Environ Health Perspect 2012, 120:A62-A68.

13. Fisher BE: Most unwanted. Environ Health Perspect 1999, 107:A18-A23.

14. Atlas E, Giam CS: Global transport of organic pollutants - ambient concentrations in the remote marine atmosphere. Science 1981, 211:163-165.

15. Bergkvist C, Oberg M, Appelgren M, Becker W, Aune M, Ankarberg EH, Berglund $M$, Hakansson $\mathrm{H}$ : Exposure to dioxin-like pollutants via different food commodities in Swedish children and young adults. Food Chem Toxicol 2008, 46:3360-3367.

16. Sasamoto T, Ushio F, Kikutani N, Saitoh Y, Yamaki Y, Hashimoto T, Horii S, Nakagawa Jl, Ibe A: Estimation of 1999-2004 dietary daily intake of PCDDs, PCDFs and dioxin-like PCBs by a total diet study in metropolitan Tokyo, Japan. Chemosphere 2006, 64:634-641.

17. Bocio A, Domingo JL: Daily intake of polychlorinated dibenzo-p-dioxins /polychlorinated dibenzofurans (PCDD/PCDFs) in foodstuffs consumed in Tarragona, Spain: a review of recent studies (2001-2003) on human PCDD/PCDF exposure through the diet. Environ Res 2005, 97:1-9.

18. Dougherty CP, Holtz SH, Reinert JC, Panyacosit L, Axelrad DA, Woodruff TJ: Dietary exposures to food contaminants across the United States. Environ Res 2000, 84:170-185.

19. Schecter A, Colacino J, Haffner D, Patel K, Opel M, Papke O, Birnbaum L. Perfluorinated compounds, polychlorinated biphenyls, and organochlorine pesticide contamination in composite food samples from Dallas, Texas, USA Environ Health Perspect 2010, 118:796-802.

20. Darnerud PO, Atuma S, Aune M, Bjerselius R, Glynn A, Grawe KP, Becker W: Dietary intake estimations of organohalogen contaminants (dioxins, PCB, PBDE and chlorinated pesticides, e.g. DDT) based on Swedish market basket data. Food Chem Toxicol 2006, 44:1597-1606.

21. Tard A, Gallotti S, Leblanc JC, Volatier JL: Dioxins, furans and dioxin-like PCBs: occurrence in food and dietary intake in France. Food Addit Contam 2007, 24:1007-1017.

22. Kiviranta $\mathrm{H}, \mathrm{O}$ vaskainen MAL, Vartiainen T: Market basket study on dietary intake of PCDD/Fs, PCBs, and PBDEs in Finland. Environ Int 2004, 30:923-932.

23. Fattore $E$, Fanelli $R$, Turrini $A$, di Domenico A: Current dietary exposure to polychlorodibenzo-p-dioxins, polychlorodibenzofurans, and dioxin-like polychlorobiphenyls in Italy. Mol Nutr Food Res 2006, 50:915-921.

24. Schecter A, Cramer P, Boggess K, Stanley J, Papke O, Olson J, Silver A, Schmitz M: Intake of dioxins and related compounds from food in the US population. J Toxicol Env Health Pt A 2001, 63:1-18.

25. Schafer KS, Kegley SE: Persistent toxic chemicals in the US food supply. J Epidemiol Comm Health 2002, 56:813-817.

26. Fromberg A, Granby K, Hojgard A, Fagt S, Larsen JC: Estimation of dietary intake of PCB and organochlorine pesticides for children and adults. Food Chem 2011, 125:1179-1187.
27. Wang SL, Tsai PC, Yang CY, Guo YL: Increased risk of diabetes and polychlorinated biphenyls and dioxins - A 24-year follow-up study of the Yucheng cohort. Diabetes Care 2008, 31:1574-1579.

28. Henriksen GL, Ketchum NS, Michalek JE, Swaby JA: Serum dioxin and diabetes mellitus in veterans of Operation Ranch Hand. Epidemiology 1997, 8:252-258.

29. Lee DH, Lee IK, Song K, Steffes M, Toscano W, Baker BA, Jacobs DR Jr: A strong dose-response relation between serum concentrations of persistent organic pollutants and diabetes: results from the National Health and Examination Survey 1999-2002. Diabetes Care 2006, 29:1638-1644.

30. Rignell-Hydbom A, Rylander L, Hagmar L: Exposure to persistent organochlorine pollutants and type 2 diabetes mellitus. Hum Exp Toxicol 2007, 26:447-452.

31. Fierens S, Mairesse H, Heilier JF, De Burbure C, Focant JF, Eppe G, De Pauw E, Bernard A: Dioxin/polychlorinated biphenyl body burden, diabetes and endometriosis: findings in a population-based study in Belgium. Biomarkers 2003, 8:529-534

32. Turyk $M$, Anderson HA, Knobeloch L, Imm P, Persky W: Prevalence of diabetes and body burdens of polychlorinated biphenyls, polybrominated diphenyl ethers, and p, p'-diphenyldichloroethene in Great Lakes sport fish consumers. Chemosphere 2009, 75:674-679.

33. Rignell-Hydbom A, Lidfeldt J, Kiviranta H, Rantakokko P, Samsioe G, Agardh $C D$, Rylander L: Exposure to p, $p$ '-DDE: A Risk Factor for Type 2 Diabetes. PLoS One 2009, 4(10):e7503.

34. Ukropec J, Radikova Z, Huckova M, Koska J, Kocan A, Sebokova E, Drobna B, Trnovec T, Susienkova K, Labudova $V$, et al: High prevalence of prediabetes and diabetes in a population exposed to high levels of an organochlorine cocktail. Diabetologia 2010, 53:899-906.

35. Codru N, Schymura MJ, Negoita S, Rej R, Carpenter DO: Diabetes an relation to serum levels of polychlorinated biphenyls and chlorinated pesticides an adult native Americans. Environ Health Perspect 2007 115:1442-1447.

36. Son HK, Kim SA, Kang JH, Chang YS, Park SK, Lee SK, Jacobs DR, Lee DH: Strong associations between low-dose organochlorine pesticides and type 2 diabetes in Korea. Environ Int 2010, 36:410-414.

37. Airaksinen R, Rantakokko P, Eriksson JG, Blomstedt P, Kajantie E, Kiviranta H: Association Between Type 2 Diabetes and Exposure to Persistent Organic Pollutants. Diabetes Care 2011, 34:1972-1979.

38. Silverstone AE, Rosenbaum PF, Weinstock RS, Bartell SM, Foushee HR, Shelton C, Pavuk M: Polychlorinated Biphenyl (PCB) Exposure and Diabetes: Results from the Anniston Community Health Survey. Environ Health Perspect. in press.

39. Lee DH, Lind M, Jacobs DR Jr, Sahlihovic S, van Bavel B, Lind L: Polychlorinated biphenyls and organochlorine pesticides in plasma predict development of type 2 diabetes in the elderly: the prospective investigation of the vasculature in uppsala seniors (PIVUS) study. Diabetes Care 2011, 34:1-7

40. Cave M, Appana S, Patel M, Falkner KC, McClain CJ, Brock G: Polychlorinated biphenyls, lead, and mercury are associated with liver disease in American adults: NHANES 2003-2004. Environ Health Perspect 2010, 118:1735-1742.

41. Goncharov A, Pavuk M, Foushee HR, Carpenter DO: Blood pressure in relation to concentrations of PCB congeners and chlorinated pesticides. Environ Health Perspect 2011, 119:319-325.

42. Lee DH, Steffes MW, Sjodin A, Jones RS, Needham LL, Jacobs DR Jr: Low dose of some persistent organic pollutants predicts type 2 diabetes: a nested casecontrol study. Environ Health Perspect 2010, 118:1235-1242

43. Turyk M, Anderson H, Knobeloch L, Imm P, Persky V: Organochlorine exposure and incidence of diabetes in a cohort of Great Lakes sport fish consumers. Environ Health Perspect 2009, 117:1076-1082.

44. Ruzzin J, Petersen R, Meugnier E, Madsen L, Lock E, Lillefosse H, Ma T, Pesenti S, Du ZY, Chavey C, et al: Persistent organic pollutant exposure leads to insulin resistance syndrome. Environ Health Perspect 2010, 118:465-471.

45. Ibrahim MM, Fjaere E, Lock E, Naville D, Amlund H, Meugnier E, Le Magueresse Battistoni $B$, Froyland L, Madsen L, Jessen N, et al: Chronic consumption of farmed salmon containing persistent organic pollutants causes insulin resistance and obesity in mice. PLoS One 2011, 6(9):e25170.

46. Croutch CR, Lebofsky M, Schramm KW, Terranova PF, Rozman KK: 2,3,7,8 Tetrachlorodibenzo-p-dioxin (TCDD) and 1,2,3,4,7,8-hexachlorodibenzo-pdioxin $(\mathrm{HxCDD})$ alter body weight by decreasing insulin-like growth factor I (IGF-I) signaling. Toxicol Sci 2005, 85:560-571. 
47. National Toxicology Program: NTP Toxicology and Carcinogenesis Studies of a Binary Mixture of 3,3',4,4',5-Pentachlorobiphenyl (PCB 126) (CAS No. 57465-28-8) and 2,2',4,4',5,5'-Hexachlorobiphenyl (PCB 153) (CAS No. 35065-27-1) in Female Harlan Sprague-Dawley Rats (Gavage Studies). Natl Toxicol Program Tech Rep Ser 2006, :1-258.

48. Arsenescu V, Arsenescu RI, King V, Swanson H, Cassis LA: Polychlorinated biphenyl-77 induces adipocyte differentiation and proinflammatory adipokines and promotes obesity and atherosclerosis. Environ Health Perspect 2008, 116:761-768

49. Grun F, Blumberg B: Endocrine disrupters as obesogens. Mol Cell Endo 2009, 304:19-29.

50. Stockholm Convention: http://chm.pops.int.

51. Jorgenson $\mathrm{J}$ : Aldrin and Dieldrin: a review of research on their production, environmental deposition and fate, bioaccumulation, toxicology and epidemiology in the United States. Environ Health Perspect 2001, 109:113-139.

52. WHO: The use of DDT in malaria vector control.2007.

53. Bouwman $\mathrm{H}$, Kylin $\mathrm{H}$ : Malaria control insecticide residues in breast milk: the need to consider infant health risks. Environ Health Perspect 2009, 117:1477-1480.

54. Bouwman $\mathrm{H}$, van den Berg $\mathrm{H}$, Kylin $\mathrm{H}$ : DDT and malaria prevention: addressing the paradox. Environ Health Perspect 2011, 119:744-747.

55. Tren R, Roberts D: DDT Paradox. Environ Health Perspect 2011, 119:A423-A424.

56. van den Berg H: Global status of DDT and its alternatives for use in vector control to prevent disease. Environ Health Perspect 2009, 117:1656-1663.

57. Van den Berg M, Birnbaum L, Bosveld ATC, Brunstrom B, Cook P, Feeley M, Giesy JP, Hanberg A, Hasegawa R, Kennedy SW, et al: Toxic equivalency factors (TEFs) for PCBs, PCDDs, PCDFs for humans and wildlife. Environ Health Perspect 1998, 106:775-792.

58. Van den Berg M, Birnbaum LS, Denison M, De Vito M, Farland W, Feeley M, Fiedler H, Hakansson H, Hanberg A, Haws L, et al: The 2005 World Health Organization reevaluation of human and Mammalian toxic equivalency factors for dioxins and dioxin-like compounds. Toxicol Sci 2006, 93:223-241.

59. Baars AJ, Bakker MI, Baumann RA, Boon PE, Freijer Il, Hoogenboom LAP, Hoogerbrugge R, van Klaveren JD, Liem AKD, Traag WA, et al: Dioxins, dioxin-like PCBs and non-dioxin-like PCBs in foodstuffs: occurrence and dietary intake in The Netherlands. Toxicol Lett 2004, 151:51-61.

60. Llobet JM, Marti-Cid R, Castell V, Domingo JL: Significant decreasing trend in human dietary exposure to PCDD/PCDFs and PCBs in Catalonia, Spain. Toxicol Lett 2008, 178:117-126.

61. Humblet O, Sergeyev O, Altshul L, Korrick SA, Williams PL, Emond C, Birnbaum LS, Burns JS, Lee MM, Revich B, et al: Temporal trends in serum concentrations of polychlorinated dioxins, furans, and PCBs among adult women living in Chapaevsk, Russia: a longitudinal study from 2000 to 2009. Environ Health 2011, 10:62

62. Wiesmuller GA, Eckard R, Dobler L, Gunsel A, Oganowski M, Schroter-Kermani C, Schluter C, Gies A, Kemper FH: The environmental specimen bank for human tissues as part of the German environmental specimen bank. Int J Hyg Environ Health 2007, 210:299-305.

63. LaKind JS, Hays SM, Aylward LL, Naiman DQ: Perspective on serum dioxin levels in the United States: an evaluation of the NHANES data. J Expo Sci Environ Epidemiol 2009, 19:435-441.

64. Furuya H, Kayama F, Hasegawa M, Nagai M, Suzuki T: A longitudinal study of trends in blood dioxins and dioxin-like compounds levels in residents from two locations in Japan during 2002-2006. Arch Environ Contam Toxicol 2010, 58:892-900.

65. Link B, Gabrio T, Mann V, Schilling B, Maisner V, Konig M, Flicker-Klein A, Zollner I, Fischer G: Polybrominated diphenyl ethers (PBDE) in blood of children in Baden-Wurttemberg between 2002/03 and 2008/09. Int J Hyg Environ Health 2012, 215:224-228.

66. Wang M, Park JS, Petreas M: Temporal changes in the levels of perfluorinated compounds in California women's serum over the past 50 years. Environ Sci Technol 2011, 45:7510-7516.

67. Kato K, Wong LY, Jia LT, Kuklenyik Z, Calafat AM: Trends in exposure to polyfluoroalkyl chemicals in the U.S. Population: 1999-2008. Environ Sci Technol 2011, 45:8037-8045.

68. European Commission: Opinion of the SCF on the risk assessment of dioxins and dioxin-like PCBs in food. 2000.

69. Gies A, Neumeier G, Rappolder M, Konietzka R: Risk assessment of dioxins and dioxin-like PCBs in food - Comments by the German Federal Environmental Agency. Chemosphere 2007, 67:S344-S349.
70. European Commission: Opinion of the SCF on the risk assessment of dioxins and dioxin-like PCBs in food. Up-date based on new scientific information. 2001.

71. Bocio A, Domingo JL, Falco G, Llobet JM: Concentrations of PCDD/PCDFs and PCBs in fish and seafood from the Catalan (Spain) market: Estimated human intake. Environ Int 2007, 33:170-175.

72. Liem AKD, Furst $P$, Rappe C: Exposure of populations to dioxins and related compounds. Food Add Cont 2000, 17:241-259.

73. Welshons W, Thayer KA, Judy BM, Taylor JA, Curran EM, Vom Saal FS: Large effects from small exposures. I. Mechanisms for endocrine-disrupting chemicals with estrogenic activity. Environ Health Perspect 2003, 111:994-1006.

74. Conolly RB, Lutz WK: Nonmonotonic dose-response relationships: mechanistic basis, kinetic modeling, and implications for risk assessment. Toxicol Sci 2004, 77:151-157.

75. Lee DH, Jacobs DR Jr, Porta M: Could low-level background exposure to persistent organic pollutants contribute to the social burden of type 2 diabetes? J Epi Com Health 2006, 60:1006-1008.

76. Lee DH, Lind L, Jacobs DR Jr, Salihovic S, van Bavel B, Lind PM: Associations of persistent organic pollutants with abdominal obesity in the elderly: The Prospective Investigation of the Vasculature in Uppsala Seniors (PIVUS) study. Environ Int 2011, 40:170-178.

77. Lee DH, Steffes MW, Sjodin A, Jones RS, Needham LL, Jacobs DR Jr: Low dose organochlorine pesticides and polychlorinated biphenyls predict obesity, dyslipidemia, and insulin resistance among people free of diabetes. PLoS One 2011, 6(1):e15977.

78. Lee DH, Lind PM, Jacobs DR Jr, Salihovic S, van Bavel B, Lind L: Polychlorinated Biphenyls and Organochlorine Pesticides in Plasma Predict Development of Type 2 Diabetes in the Elderly: The Prospective Investigation of the Vasculature in Uppsala Seniors (PIVUS) Study. Diabetes Care 2011, 34:1778-1784.

79. Ruzzin J: Mechanistic basis for elevation in risk of diabetes caused by persistent organic pollutants. In Effects of persistent and bioactive organic pollutants on human health. Edited by Carpenter DO: John Wiley \& Sons, Inc; in press.

80. Casals-Casas C, Desvergne B: Endocrine disruptors: from endocrine to metabolic disruption. Annu Rev Physiol 2011, 73:135-162.

81. Bencko V, Cerna M, Jech L, Smid J: Exposure of breast-fed children in the Czech Republic to PCDDs, PCDFs, and dioxin-like PCBs. Environ Toxicol Pharmacol 2004, 18:83-90.

82. Focant JF, Pirard C, Thielen C, De Pauw E: Levels and profiles of PCDDs, PCDFs and CPCBs in Belgian breast milk. Estimation of infant intake Chemosphere 2002, 48:763-770.

83. Furst P: Dioxins, polychlorinated biphenyls and other organohalogen compounds in human milk - Levels, correlations, trends and exposure through breastfeeding. Mol Nutr Food Res 2006, 50:922-933.

84. Hsu JF, Guo YL, Liu CH, Hu SC, Wang JN, Liao PC: A comparison of PCDD/ PCDFs exposure in infants via formula milk or breast milk feeding. Chemosphere 2007, 66:311-319.

85. Patandin S, Dagnelie PC, Mulder PGH, de Coul EO, van der Veen JE, Weisglas-Kuperus N, Sauer PJJ: Dietary exposure to polychlorinated biphenyls and dioxins from infancy until adulthood: A comparison between breast-feeding, toddler, and longterm exposure. Environ Health Perspect 1999, 107:45-51

86. Wittsiepe J, Schrey P, Wilhelm M: Dietary intake of PCDD/F by small children with different food consumption measured by the duplicate method. Chemosphere 2001, 43:881-887.

87. Weijs PJM, Bakker MI, Korver KR, Ghanaviztchi KV, van Wijnen JH: Dioxin and dioxin-like PCB exposure of non-breastfed Dutch infants. Chemosphere 2006, 64:1521-1525.

88. Bearer CF: How are children different from adults. Environ Health Perspect 1995, 103:7-12.

89. Anway MD, Cupp AS, Uzumcu M, Skinner MK: Epigenetic transgenerational actions of endocrine disruptors and mate fertility. Science 2005, 308:1466-1469.

90. Hites RA, Foran JA, Carpenter DO, Hamilton MC, Knuth BA, Schwager SJ: Global assessment of organic contaminants in farmed salmon. Science 2004, 303:226-229.

91. Budtz-Jorgensen E, Grandjean P, Weihe P: Separation of risks and benefits of seafood intake. Environ Health Perspect 2007, 115:323-327.

92. Bushkin-Bedient S, Carpenter DO: Benefits versus risks associated with consumption of fish and other seafood. Rev Environ Health 2010, 25:161-191. 
93. Commission Regulation: Amending regulation (EC) No 466/2001 setting maximum levels for certain contaminants in foodstuffs as regards dioxins and dioxin-like PCBs. Official Journal of the European Union 2006 No 199/2006.

94. Xu XH, Dailey AB, Talbott EO, llacqua VA, Kearney G, Asal NR: Associations of serum concentrations of organochlorine pesticides with breast cancer and prostate cancer in US adults. Environ Health Perspect 2010, 118:60-66.

95. Richardson JR, Shalat SL, Buckley B, Winnik B, O'Suilleabhain P, Diaz-Arrastia R, Reisch J, German DC: Elevated serum pesticide levels and risk of Parkinson disease. Arch Neurol 2009, 66:870-875.

96. Commission Regulation: Amending regulation (EC) No 396/2005 on maximum residue levels of pesticides in or on food and feed of plant and animal origin, as regards the implementing powers conferred on the commission. Official Journal of the European Union 2008, No 299/2008.

97. Djousse L, Gaziano JM, Buring JE, Lee IM: Dietary omega-3 fatty acids and fish consumption and risk of type 2 diabetes. Am J Clin Nutr 2011, 93:143-150.

98. Kaushik M, Mozaffarian D, Spiegelman D, Manson JE, Willett WC, Hu FB: Long-chain omega- 3 fatty acids, fish intake, and the risk of type 2 diabetes mellitus. Am J Clin Nutr 2009, 90:613-620.

99. Patel PS, Bingham SA, Sharp SJ, Wareham NJ, Luben RN, Forouhi NG, Khaw $\mathrm{KT}$ : Association between type of dietary fish and seafood intake and the risk of incident type 2 diabetes the European prospective investigation of cancer (EPIC)-Norfolk cohort study. Diabetes Care 2009, 32:1857-1863.

100. Crinnion WJ: The Role of persistent organic pollutants in the worldwide epidemic of type 2 diabetes mellitus and the possible connection to farmed Atlantic Salmon (Salmo salar). Alter Med Review 2012, 16:301-313.

doi:10.1186/1471-2458-12-298

Cite this article as: Ruzzin: Public health concern behind the exposure to persistent organic pollutants and the risk of metabolic diseases. BMC Public Health 2012 12:298.

\section{Submit your next manuscript to BioMed Central and take full advantage of:}

- Convenient online submission

- Thorough peer review

- No space constraints or color figure charges

- Immediate publication on acceptance

- Inclusion in PubMed, CAS, Scopus and Google Scholar

- Research which is freely available for redistribution 